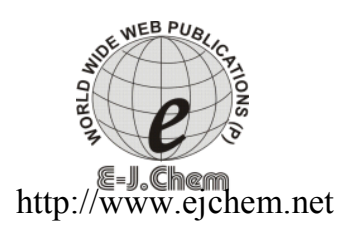

ISSN: 0973-4945; CODEN ECJHAO

E-Journal of Chemistry

2012, 9(3), 1373-1388

\title{
Alkali Activation of Oil Shale Ash Based Ceramics
}

\author{
A. HAMADI* and K. NABIH* \\ *Laboratoire de Chimie du Solide Appliquée, Faculté des Sciences, Département de Chimie \\ Avenue Ibn Batouta \\ B.P. 1014 Rabat, Morocco \\ hamadi_13@yahoo.fr
}

Recieved 10 June 2011; Accepted 13 August 2011

\begin{abstract}
Timahdit oil shale was subjected to firing transformation via ceramics processing followed by alkali activation to synthesis a materials combining the mechanical properties of ceramics and Zeolites. The mineralogical transformations during firing oil shale have been studied. The main crystalline phases found in oil shale ash (OSA) were wollastonite, gehlenite and augite. Modified oil shale ash (MOSA) was obtained with $\mathrm{HNO}_{3}$ acid-leaching in the aim to diminish Ca content. Our experimental approach required a $\mathrm{NaOH}$ alkaline activating solution with different concentrations $(0.5 ; 1 ; 2 ; 4 ; 6$ and $8 \mathrm{M})$. In our study, X-ray diffraction (XDR), Fourier transform infrared (FTIR) and SEM/EDS analysis were used to evaluate the effect of alkali activation on the structural arrangement of the starting materials (OSA and MOSA) in our study. The quantity and the type of the produced zeolites depended critically on the starting materials and on the $\mathrm{NaOH}$ concentration.
\end{abstract}

Keywords: oil shale, firing transformation, ceramics, alkali activation, Zeolites.

\section{Introduction}

Oil shale will be one of the most interesting energy and chemical sources in the world after the exhaustion of oil deposits. Morocco is one of the world leading countries in term of oil shale resources. These natural resources are very promising. They are estimated in Tarfaya deposit, located in the southwestern part of Morocco at 86 billion tons within a $2000 \mathrm{~km}^{2}$ area and in Timahdet deposit, located about $250 \mathrm{~km}$ southeast of the capital Rabat, at 18 billion tons within a $196 \mathrm{~km}^{2}$ area [1 ].

Mining and processing of the oil-shale will significantly disturb the environment, as a result of pollution by dust particles and ash derived from the oil shale [2, 3]. Valorisation of these valuable by product will reduce the environmental impact and will make oil shale development economically feasible for energy production in the future.

Oil shale ash (OSA) is used as raw material for cement and brick production $[4,5,6]$. Nevertheless the major amount is disposed as landfill. More efforts are required for developing new potential utilisations. Recently new processes are being investigated. The 
similarity of mineralogical composition of oil shale ash with clay minerals has been reported [7]. Jingde et al [8] used a Chinese oil shale ash for the synthesis of glass-ceramics, which are usually produced from mineral clays. Hajjiji et al [9] studied the ceramics properties of Moroccan oil shale ash. Although, alkali activation of oil shale ash has been investigated for Zeolites production . Fernandes Machado et al [10]synthesized Na-A and -X Zeolites from Brazilian oil shale ash through two methods, studying the cristallinity of reaction products for each method. Shawabkeh et al [11] converted Jordanian oil shale ash to the NaP1 zeolites and studied their potential applications for cation exchange capacity and adsorption propriety.

In our study we applied a ceramics processing to Timahdit oil shale followed by alkali activation of the resulting materials in the aim to combine the physical properties of ceramics and Zeolites materials. In order to optimize the experimental conditions oil shale ash heat treatment was carried out at $900^{\circ}$ without any nucleating agent. Formation of augite simultaneously with gehlenite and wollastonite was characterized by X-ray diffraction (XRD), scanning electron microscopy (SEM) and Fourier transform infrared (FT-IR) spectroscopy. Alkali activation of the OSA via refluxing method was also investigated. The effect of starting material and the $\mathrm{NaOH}$ concentration on the Zeolites formation was discussed.

\section{Materials and Methods}

Timahdit oil shale used in our study was obtained from The ONHYM (Office National des Hydrocarbures et des Mines) [1]. Oil shale was grinded to small sizes $(<1 \mathrm{~mm})$ and placed in porcelain crucibles. Samples were fired in a tubular laboratory furnace for 20 hours at $900^{\circ} \mathrm{C}$ under atmospheric conditions. The furnace power turned off leading a slow cooling down of the samples. Modified oil shale ash was obtained by an acid treatment of fired oil shale ash; the process was carried out as follow: $10 \mathrm{~g}$ was leached with $5 \mathrm{M} \mathrm{HNO}_{3}$ solution $(40 \mathrm{ml})$ at ambient temperature with continuous stirring system for $24 \mathrm{~h}$. solid product were filtered-off, washed and dried at $100^{\circ} \mathrm{C}$ for $24 \mathrm{~h}$. The chemical composition of the oil shale ash (OSA) and the modified oil shale ash (MOSA) was determined by X-ray fluorescence (Philips, PW 2404, Magix Pro) (Table 1).

Table 1: Chemical composition of OSA and MOSA (\%wt).

\begin{tabular}{ccc}
\hline Compound & Oïl shale ash $($ OSA $)$ & Modified oil shale ash (MOSA) \\
\hline $\mathrm{Na}_{2} \mathrm{O}$ & 0.31 & 0.09 \\
$\mathrm{MgO}$ & 4.88 & 3.34 \\
$\mathrm{Al}_{2} \mathrm{O}_{3}$ & 11.33 & 5.67 \\
$\mathrm{SiO}_{2}$ & 33.36 & 76.37 \\
$\mathrm{P}_{2} \mathrm{O}_{5}$ & 1.31 & 0.07 \\
$\mathrm{SO}_{3}$ & 4.92 & 0.10 \\
$\mathrm{~K}_{2} \mathrm{O}$ & 1.06 & 0.31 \\
$\mathrm{CaO}$ & 38.74 & 8.14 \\
$\mathrm{TiO}_{2}$ & 0.46 & 0.75 \\
$\mathrm{Fe}_{2} \mathrm{O}_{3}$ & 3.31 & 4.81 \\
$\mathrm{MnO}$ & 0.03 & 0.02 \\
$\mathrm{Total}$ & 100.00 & 100,00 \\
\hline
\end{tabular}


The synthesis method was based on the work of Henmi et al [12]. To understand the effect of $\mathrm{NaOH}$ concentration, a series of experiments were undertaken to determine phase chemistry of the products. Alkaline activation of oil shale ash was carried out as follow: $5 \mathrm{~g}$ of OSA was mixed with $0.5,1,2,4,6$ and $8 \mathrm{M} \mathrm{NaOH}$ solutions $(50 \mathrm{ml})$ in a Pyrex Becker, the mixture was stirred for 1 hour to create homogenous gel. Liquid/solid ration was fixed at 10. Refluxing process was carried out in Pyrex one-neck round-bottom flask in a heating mantle temperature was maintained at $100{ }^{\circ} \mathrm{C}$. Heating period was fixed at $24 \mathrm{~h}$ for all experiments. Same process was followed for the Modified oil shale ash. Mineralogical composition of the starting materials and the reaction products was determined by X-ray by powder X-ray diffraction (PANalytical's X'Pert PRO X-ray diffractometer with $\mathrm{Cu} \mathrm{K \alpha}$ radiation). Major and minor phases were performed with semi-quantitative method on the basis of the intensity (counts) of specific reflections, the density, and the mass absorption coefficient $(\mathrm{Cu} \mathrm{K \alpha})$ of the identified mineral phases [13, 14]. FTIR characterization of oil shale ashes and reaction products was conducted with a VERTEX 70 spectrometer equipped with digitec detector. The $\mathrm{KBr}$ pellet method was used to prepare the samples which were scanned in transmission mode with $4 \mathrm{~cm}^{-1}$ resolution at the range of 4000 to $400 \mathrm{~cm}^{-1}$. The morphology of oil shale ash and synthetic products was observed by JEOL JMS 5500 scanning electron microscope, equipped with SUTW-Sapphire detector for EDX analysis using a ZAF method for the quantification. The experimental conditions and the reaction products as well as the characterization tools are summarized in Table 2.

Table 2. Experimental conditions and characterization tools employed in the alkali activation of the oil shale ash (OSA) and the modified oil shale (MOSA).

\begin{tabular}{|c|c|c|c|c|c|c|c|c|c|}
\hline $\begin{array}{l}\text { Starting } \\
\text { material }\end{array}$ & $\begin{array}{c}\text { Test } \\
\text { symbol }\end{array}$ & $\begin{array}{c}\mathrm{NaOH} \\
\text { concentration }\end{array}$ & $\begin{array}{c}\mathrm{L} / \mathrm{S} \\
\text { ratio } \\
(\mathrm{ml} / \mathrm{g})\end{array}$ & $\mathrm{T}\left(\mathrm{C}^{\circ}\right)$ & $t(h)$ & XRD & FTIR & SEM/EDAX & $\begin{array}{l}\text { Reaction } \\
\text { products }\end{array}$ \\
\hline
\end{tabular}

\begin{tabular}{cccccccccc}
\hline & ZB1 & 0.5 & 5 & 100 & 24 & + & + & & -- \\
Oil shale & ZB2 & 1 & 5 & 100 & 24 & + & + & + & Tob \\
Ash & ZB3 & 2 & 5 & 100 & 24 & + & + & & Tob \\
(OSA) & ZB4 & 4 & 5 & 100 & 24 & + & + & + & Tob, Can \\
$(5 \mathrm{~g})$ & ZB5 & 6 & 5 & 100 & 24 & + & + & & Tob, Can \\
& ZB6 & 8 & 5 & 100 & 24 & + & + & + & Tob, Can \\
\hline \multirow{2}{*}{ Modified } & Z'B1 & 0.5 & 5 & 100 & 24 & + & + & & -- \\
Oil shale & Z'B2 & 1 & 5 & 100 & 24 & + & + & & Ana \\
Ash & Z'B3 & 2 & 5 & 100 & 24 & + & + & & Ana \\
(MOSA) & Z'B4 & 4 & 5 & 100 & 24 & + & + & + & Ana \\
(5g) & Z'B5 & 6 & 5 & 100 & 24 & + & + & & Can \\
& Z'B6 & 8 & 5 & 100 & 24 & + & + & + & Can \\
\hline
\end{tabular}

Tob: Tobermorite; Can: Cancrinite; Ana: Analcime. 


\section{Results and Discussion}

\section{Mineralogical characterization}

The mineral phases of oil shale, as identified by XRD (not showed here), consists mainly of Calcite, Quartz, Dolomite and Clays .Minor phases include pyrite, hydroxyl-apatite, anhydrite and feldspars.

\section{Oil shale ash (OSA) and Modified oil shale ash(MOSA)}

During heat treatment, calcite, dolomite and clays have been decomposed respectively to $\mathrm{CaO}$, $\mathrm{MgO}$ and $\mathrm{Al}_{2} \mathrm{O}_{3}$. Wollastonite [15] is the first abundant phase formed, resulting from the reaction of $\mathrm{CaO}$ with $\mathrm{SiO}_{2}$ following the reactions of Peters and Iberg 1978[16](equation 1), while the reaction of $\mathrm{CaO}$ and $\mathrm{SiO}_{2}$ with $\mathrm{Al}_{2} \mathrm{O}_{3}$ leads to the formation of gehlenite[17] (equation 2).Nevertheless gehlenite is considered as metastable phase in the presence of $\mathrm{MgO}$ and $\mathrm{Fe}_{2} \mathrm{O}_{3}$ which leads to the apparition of augite[18,19] (equation3).

$$
\mathrm{CaCO}_{3}(\text { Calcite })+\mathrm{SiO}_{2} \rightarrow \mathrm{CO}_{2}+\mathrm{CaSiO}_{3} \text { wollastonite (1) }
$$

illite $\mathrm{KAl}_{2}\left(\mathrm{Si}_{3} \mathrm{Al}\right) \mathrm{O}_{10}(0 \mathrm{H})_{2}+6 \mathrm{CaCO}_{3}$ (calcite $) \rightarrow 6 \mathrm{CO}_{2}+2 \mathrm{H}_{2} \mathrm{O}+\mathrm{K}_{2} \mathrm{O}+3 \mathrm{SiO}_{2}+$

3Ca2Al2Si2O gehlenite (2)

$$
\left.\mathrm{Ca}_{2} \mathrm{Al}_{2} \mathrm{Si}_{2} \mathrm{O}_{7}+\mathrm{CO}_{2} \rightarrow \mathrm{CaCO}_{3}+(\mathrm{Ca}, \mathrm{Mg}, \mathrm{Al}, \mathrm{Fe})(\mathrm{Si}, \mathrm{Al}) \mathrm{O}_{3}\right)_{2} \text { augite (3) }
$$

The XRD spectrum of the oil shale ash shows also the presence of quartz [20] and anhydrite [21]. The existence of an amorphous phase is attested by the background noise (Fig. 1).

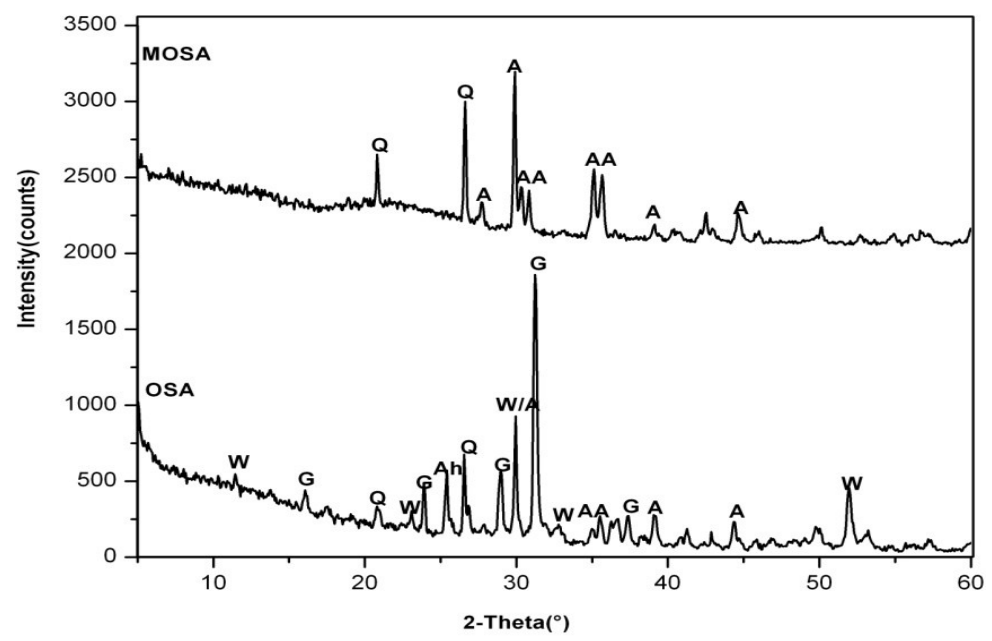

Figure 1. XRD patterns of oil shale ash (OSA) and modified oil shale ash (MOSA).

Q: Quartz, W: Wollastonite, A: Augite, G: Gehlenite, Ah: Anhydrites.

After acid treatment only augite and quartz were present as shown by XRD (Fig.1). In fact these materials have a lower solubility in $\mathrm{HNO}_{3}$ acid solution [22]. Based on semiquantitative analysis, the mineralogical analysis of OSA and MOSA is shown in Table 3. 
Table 3. Mineralogical analysis of Timahdet OSA and MOSA ( $\% \mathrm{w} / \mathrm{w})$.

\begin{tabular}{ccc}
\hline Minerals & OSA & MOSA \\
\hline Wollastonite & 23.5 & - \\
Gehlenite & 13.9 & - \\
Augite & 20.3 & 34.3 \\
Quartz & 04.4 & 15.7 \\
Anhydride & 08.5 & - \\
Amorphous & 29.4 & 50.0 \\
\hline
\end{tabular}

\section{Alkali activated Oil shale ash (OSA)}

The X-ray diffraction patterns of the activated oil shale ash with different $\mathrm{NaOH}$ concentration solutions are presented in fig. 2. When the OSA was activated with $0.5 \mathrm{M}$ $\mathrm{NaOH}$ solution, the characteristic peaks of wollastonite, gehlenite and augite decreased this behavior continued with increasing $\mathrm{NaOH}$ concentration, nevertheless the dissolution of gehlenite was more important than augite and wollastonite. Dissolution of quartz started when the $\mathrm{NaOH}$ was set at $1 \mathrm{M}$, the intensity of the characteristic peak at $26.62(2 \theta)$ decreased and tended to disappear in high $\mathrm{NaOH}$ solution. The $2 \theta$ position at 29.97 was supposed to decrease due to the alkaline attack, in contrast we observed this position growing more intense with increasing $\mathrm{NaOH}$ concentration, this can be explained by the formation of tobermorite [23] which have a basal reflection (220) at the same $2 \theta$ position as augite and wollastonite [24].It can also be observed the apparition of new peaks related to tobermorite. It should be noted that the persistence of augite and wollastonite is denoting the presence of tobermorite hence its presence was confirmed by SEM/EDX analysis.

Cancrinite [25] is the main zeolitic phase formed and only when the concentration of $\mathrm{NaOH}$ solution is $\geq 2 \mathrm{M}$. The high percentage was realized for high $\mathrm{NaOH}$ concentration ( $9 \%$ ).

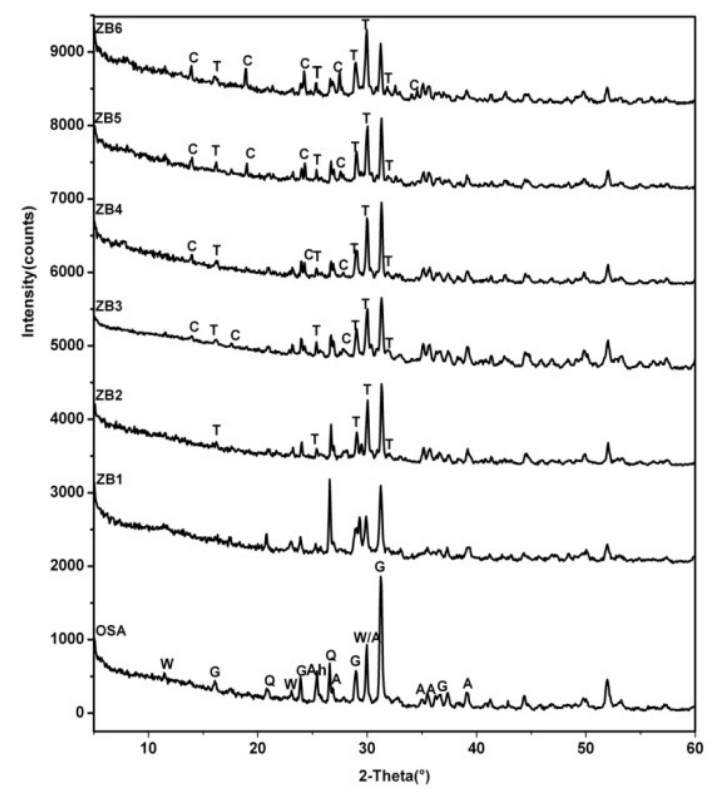

Figure 2. XRD patterns of alkali activated OSA.

Q: Quartz, W: Wollastonite, A: Augite, G: Gehlenite, Ah: Anhydrites T: Tobermorite, C: Cancrinite. 


\section{Alkali activated Modified oil shale ash (MOSA)}

Fig. 3 presents the X-ray diffraction patterns of the activated modified oil shale ash. We observed that the characteristic peak of quartz at $26.62(2 \theta)$ increased with increasing $\mathrm{NaOH}$ concentration, while the characteristic peak of augite at 29.97 attaining the limit in $4 \mathrm{M}$ $\mathrm{NaOH}$ solutions. The XRD pattern of the reaction product Z'B2 obtained in $1 \mathrm{M} \mathrm{NaOH}$ solution shows the presence of analcime [26], this is the main zeolitic phase formed in this experimental conditions. The high cristallinity of analcime $(25 \%)$ is observed in $4 \mathrm{M} \mathrm{NaOH}$ solution (Z'B4). When the $\mathrm{NaOH}$ concentration was $>4 \mathrm{M}$, a minor cancrinite phase [27] was formed, the percentage of this Zeolites does not exceed $12 \%$. This can suggests that the excess of $\mathrm{NaOH}$ concentration $(>4 \mathrm{M})$ plays a disadvantageous role on the Zeolites formation [22].

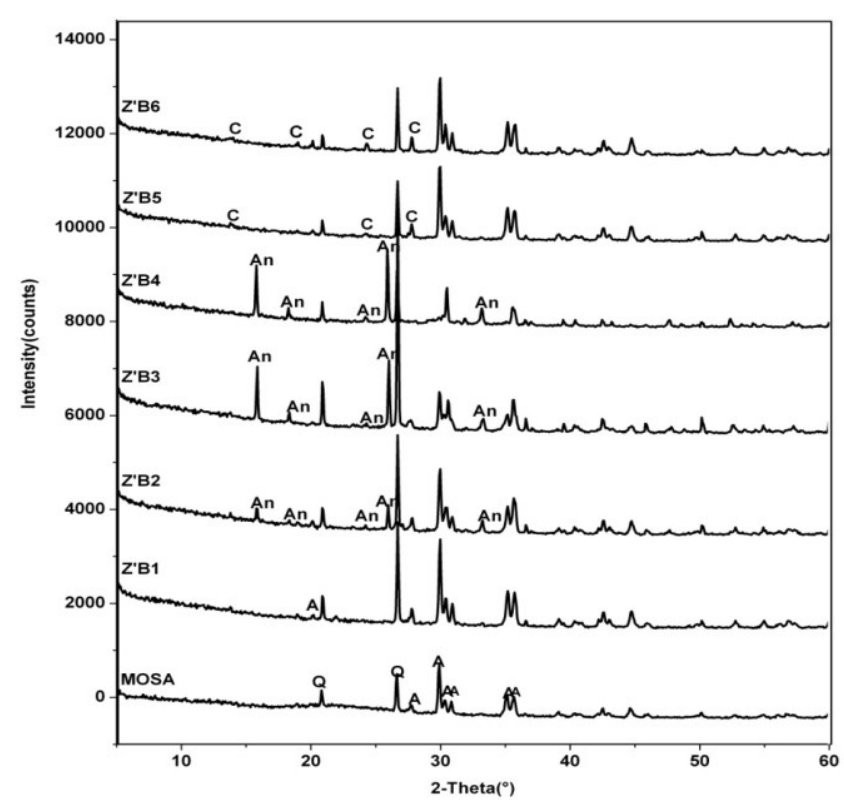

Figure 3. XRD patterns of alkali activated MOSA. Q: Quartz, A: Augite, An: Analcime, C: Cancrinite.

Table 4. Identified minerals in Timahdet OSA and MOSA and in the reactions product.

\begin{tabular}{cccc}
\hline Phase & Chemical formula & $\begin{array}{c}\text { ICDD Card } \\
\text { No }\end{array}$ & Reference \\
\hline Wollastonite & $\mathrm{CaSIO}_{3}$ & $84-0654$ & Ohashi Y. [15] \\
Gehlenite & $\mathrm{Ca}_{2} \mathrm{Al}_{2} \mathrm{SiO}_{7}$ & $73-2041$ & Raaz F. [17] \\
Augite & $\mathrm{Al}_{1,38} \mathrm{Ca}_{0,74} \mathrm{Fe}_{0,16} \mathrm{Mg}_{0,01} \mathrm{O}_{6} \mathrm{Si}_{1,5}$ & $89-5691$ & Okui M. [18] \\
Quartz & $\mathrm{SiO}_{2}$ & $46-1045$ & Kern A. [20] \\
Anhydride & $\mathrm{CaSO}_{4}$ & $72-0503$ & Cheng G.C.H. [21] \\
Tobermorite & $\mathrm{Ca}_{5}(\mathrm{O} \mathrm{H})_{2} \mathrm{Si}_{2} \mathrm{O}_{16} \cdot 4\left(\mathrm{H}_{2} 0\right)$ & $19-1364$ & Takahashi A. [23] \\
Cancrinite & $\mathrm{Na}_{7.86}\left(\mathrm{Al}_{6} \mathrm{Si}_{6} \mathrm{O}_{24}\right)\left(\mathrm{CO}_{3}\right)\left(\mathrm{H}_{2} 0\right)_{3.3}$ & $89-8047$ & Smolin Y. I. [25] \\
Analcime & $\mathrm{Na}_{0,93}\left(\mathrm{AlSi}_{2} \mathrm{O}_{6}\left(\mathrm{H}_{2} \mathrm{O}\right)\right.$ & $89-6324$ & Yokomori Y. [26] \\
Cancrinite & $\mathrm{Na}_{8}\left(\mathrm{AlSiO}_{4}\right)_{6}\left(\mathrm{CO}_{3}\right)\left(\mathrm{H}_{2} \mathrm{O}\right)_{2}$ & $72-2076$ & Hackbarth K. [27] \\
\hline *: Cancrinite found in reaction products using OSA as starting material.
\end{tabular}


**: Cancrinite found in reaction products using MOSA as starting material.

The chemical form of each of the new minerals fond in Timahdet OSA and MOSA and the Zeolites found in reactions products is shown in Table 4, along with database powder diffraction file (PDF-2) from international center for diffraction data (ICDD) codes for XRD identification.

\section{Fourier transformer infrared spectroscopy:}

\section{Oil shale ash (OSA)}

The FT-IR spectrum in the region of $1200-400 \mathrm{~cm}^{-1}$ of the oil shale ash is illustrated in Fig. 4. The most intense bands are ranged between 1200 and $850 \mathrm{~cm}^{-1}$, the next between $400-$ $550 \mathrm{~cm}^{-1}$, while the least intensive lies between $550-850 \mathrm{~cm}^{-1}$. The bands in the $850-1200$ $\mathrm{cm}^{-1}$ are attributed to the asymmetric stretching $(\mathrm{O}-\mathrm{Si}-\mathrm{O})$ and $(\mathrm{Si}-\mathrm{O}-\mathrm{Si})$ vibrations[28]. Referring to the work of Sterns[29], the bands with high intensities in this range can be attributed to $\mathrm{Si}-\mathrm{O}(\mathrm{Si})$ bridge bonds rather than $\mathrm{Si}-\mathrm{O}$ terminal bonds. Consequently, the two intense bands at 1020 and $971 \mathrm{~cm}^{-1}$ can be assigned to $\mathrm{Si}-\mathrm{O}-\mathrm{Si}$ bridge bonds. The signals at 937,908 and $860 \mathrm{~cm}^{-1}$ are attributed to $\mathrm{Si}-\mathrm{O}$ terminal bonds. According to literature, all of these bands can indicate the presence of wollastonite, gehlenite, and augite minerals in oil shale ash $[29,30,31,32]$. In the range of $850-550 \mathrm{~cm}^{-1}$, three bands in oil shale ash spectrum due to the deformations of the Si-O-Si linkages, are detected at $567 \mathrm{~cm}^{-1}, 645$ and $677 \mathrm{~cm}^{-1}$ they are attributed to the wollastonite[31.32]. Besides them others signals were observed at 604,712 and $825 \mathrm{~cm}^{-1}$ they were attributed to $\mathrm{SO}_{3}{ }^{2-}$ and Carbonates. The last range between $550-400 \mathrm{~cm}^{-1}$ was less studied. In fact several bands with different vibration mode can overlap in this range. An assignment was mad according to literature. The bands located at 515 and $478 \mathrm{~cm}^{-1}$ can be attributed to bending $\mathrm{O}_{\text {(terminal) }}-\mathrm{Mg}-\mathrm{O}_{\text {(terminal) }}$ bonds vibration, while the band located at 422 and $437 \mathrm{~cm}^{-1}$ can be attributed to the stretching Al-O vibrations of the $\mathrm{AlO}_{6}$ tetrahedra[30].

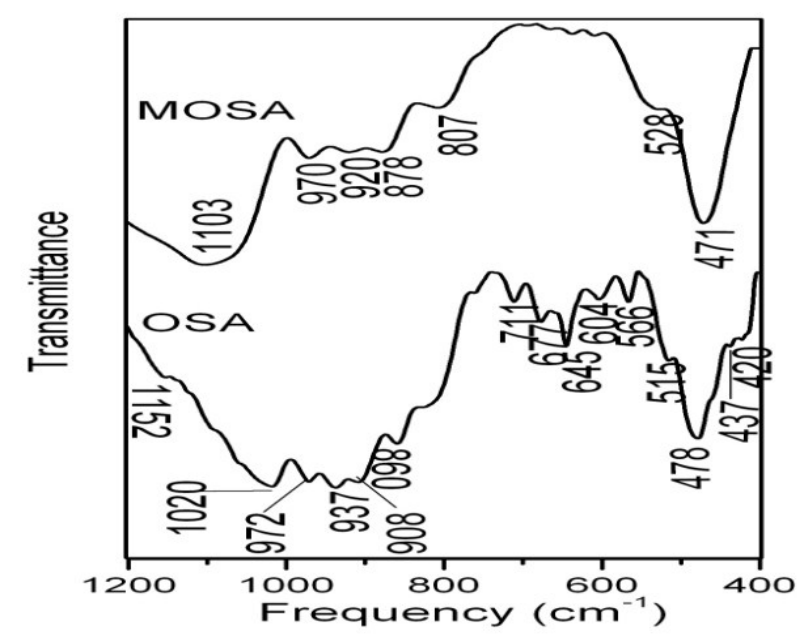

Figure 4. FTIR spectra of the firing oil shale (OSA) and the modified oil shale ash (MOSA). 
The second FT-IR spectrum in Fig.4 represents the modified oil shale ash (MOSA) sample, in the region of $1200-400 \mathrm{~cm}^{-1}$. The spectrum shows that the sample consist mainly of bands related to augite mineral (see Table 5).

The band appearing around at $1100 \mathrm{~cm}^{-1}$, according to Hamilton [36] this broad band is commonly found in the spectra of augite with low $(<15 \%)$ Ca content, other characteristic band is centered at $972 \mathrm{~cm}^{-1}$ which can be attributed to stretching Si-O-Si bridge vibration, where as the bands located at 920 and $877 \mathrm{~cm}^{-1}$ corresponds to $\mathrm{Si}-\mathrm{O}(\mathrm{Si})$ terminal vibration. Three bands with low intensities are located at 609,638 and $665 \mathrm{~cm}^{-1}$, they're attributed to the deformation of the $\mathrm{Si}-\mathrm{O}-\mathrm{Si}$ linkages. We notice that the band $638 \mathrm{~cm}^{-1}$ confirms the existence of crystalline structure of augite (Griffiths, 1987) [37]. The bands located at 528 and $471 \mathrm{~cm}^{-1}$ can be attributed to the bending vibration of $\mathrm{Si}-\mathrm{O}-\mathrm{Al}$ linkages (lin and hwang, 1996) [38].

Table 5. The bands in FTIR spectrum of Augite compared to corresponding literature data. Augite

\begin{tabular}{cccc}
\hline This work & Goel [26] & Makreski[27] & Nicodom [28] \\
\hline & & & \\
$1103 \mathrm{vs}^{*}$ & $1072 \mathrm{vs}$ & $1075 \mathrm{vs}$ & $1070 \mathrm{vs}$ \\
$970 \mathrm{~m}$ & $975 \mathrm{vs}$ & $974 \mathrm{~s}$ & $965 \mathrm{vs}$ \\
$920 \mathrm{~m}$ & ---- & $919 \mathrm{w}$ & $920 \mathrm{w}$ \\
$877 \mathrm{~m}$ & $875 \mathrm{~s}$ & $872 \mathrm{vs}$ & $865 \mathrm{~s}$ \\
$665 \mathrm{w}$ & $674 \mathrm{w}$ & $673 \mathrm{w}$ & $675 \mathrm{w}$ \\
$638 \mathrm{w}$ & $638 \mathrm{~m}$ & $634 \mathrm{~m}$ & $635 \mathrm{~m}$ \\
$528 \mathrm{~m}$ & $520 \mathrm{~m}$ & $521 \mathrm{~m}$ & $510 \mathrm{~m}$ \\
$471 \mathrm{vs}$ & $478 \mathrm{vs}$ & $469 \mathrm{vs}$ & $465 \mathrm{vs}$ \\
\hline & $*: \mathrm{s}:$ strong, w : weak, m :medium, v : very. & \\
\hline
\end{tabular}

\section{Alkali activated Oil shale ash (OSA)}

As showed in X-ray diffraction analysis, activated fired oil shale contains unreacted crystalline phases and $\mathrm{Na}$ aluminosilicates gel as principal product and zeolites as minority reaction products. Due to their similar constitution $\left(\mathrm{SiO}_{4}\right.$ and $\mathrm{AlO}_{4}$ tetrahedra), the vibrations of the bands related to the different phases of the reaction products may certainly overlap, this situation can render the interpretation of their FTIR spectra more difficult [39].

The FT-IR spectra of activated oil shale ash are given in Fig.5. The bands at 1020 and 972 $\mathrm{cm}^{-1}$ which corresponds to $\mathrm{Si}-\mathrm{O}-\mathrm{Si}$ bridge vibrations, shifted slightly to lower frequencies with increasing $\mathrm{NaOH}$ concentration, suggesting a small structural changes of the $\mathrm{Ca}$ silicates materials present in oil shale ash and occurring the to the material a mechanical strength and alkali resistance properties . The bands at 860,908 and $937 \mathrm{~cm}^{-1}$ which correspond to $\mathrm{Si}-\mathrm{O}^{-}$terminal vibrations, show a decreasing behaviors in their intensities as $\mathrm{NaOH}$ concentration increase, still the band around $937 \mathrm{~cm}^{-1}$ tends to disappear Indicating 
the polymerization of a new sodium aluminosilicates material. In the range of $500-800 \mathrm{~cm}^{-1}$, new bands appeared in spectra of activated oil shale ash which is treated with $\mathrm{NaOH}$ concentration superior to 4M. The bands at 763 and $681 \mathrm{~cm}^{-1}$ are attributed to symmetric $\mathrm{Al}-\mathrm{O}-\mathrm{Si}$ vibration related to Zeolites materials, while the band at $623 \mathrm{~cm}^{-1}$ is attributed to the 6-memebered double-ring vibration of cancrinite [40,41]. We should notice that the bands detected in this range are very weak. The band at $460 \mathrm{~cm}^{-1}$ which is attributed to the internal linkage of the $\mathrm{T0}_{4}(\mathrm{~T}=\mathrm{SI}, \mathrm{Al})$ tetrahedra related to zeolites materials can give us an information about the degree of crystallization of these materials [42].

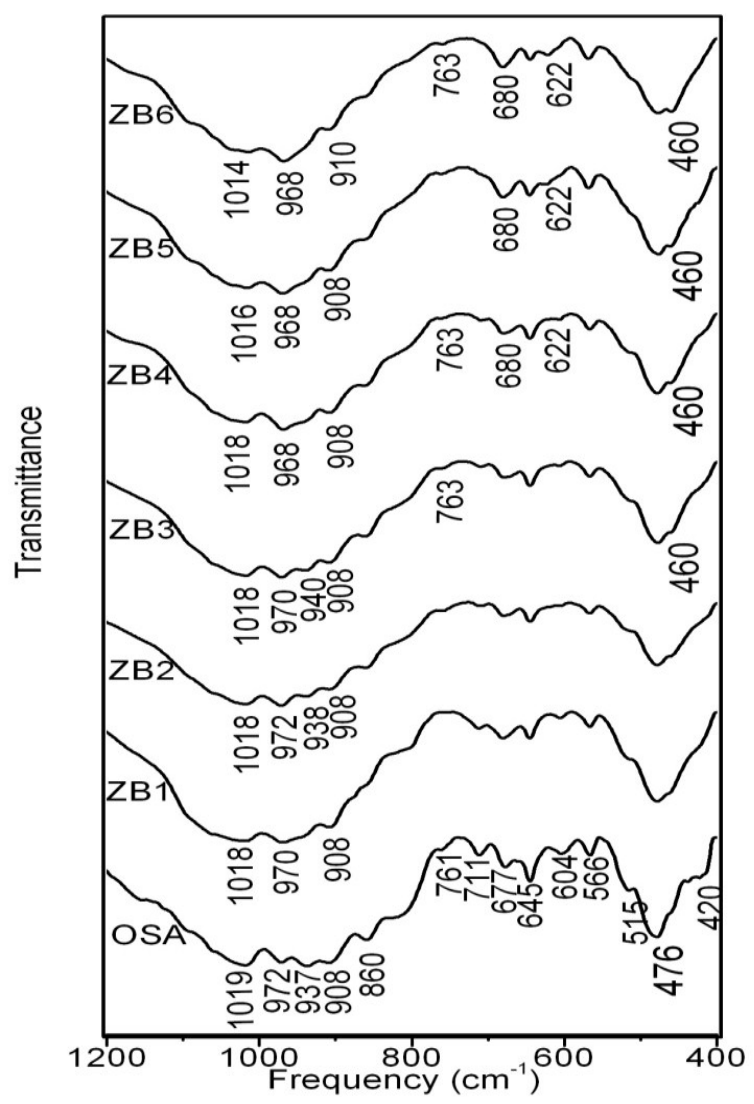

Figure 5. FTIR of the activated OSA.

\section{Alkali activated Modified oil shale ash (MOSA)}

The spectra of activated modified oil shale ash show interesting changes (Fig.6). As can be seen in the spectrum of the starting activation $(0,5 \mathrm{M} \mathrm{NaOH})$, the band at $1103 \mathrm{~cm}^{-1}$ observed in MOSA disappeared and a new band was formed at $1062 \mathrm{~cm}^{-1}$ associated to bridging stretching $\mathrm{Si}-\mathrm{O}-\mathrm{Si}_{\mathrm{b}}$ (b:bridge) vibrations of the polymerized sodium aluminosilicates (Na-Al-Si-H). with increasing $\mathrm{NaOH}$ solution concentration, this band followed a pendular movement, moving first to lower and later moved back to higher frequencies, this behavior is related to $\mathrm{Al} / \mathrm{Si}$ ratio of the reaction product, as reported early by Criado [43]. The second bridging stretching Si-O-Si $i_{b}$ vibrations at $970 \mathrm{~cm}^{-1}$ shifted slightly to higher frequencies than moved back to lower frequencies . The $\mathrm{Si}-\mathrm{O}^{-}$terminal bonds observed initially in MOSA spectrum at 920 and $877 \mathrm{~cm}^{-1}$ decreased first in their 
intensities with increasing $\mathrm{NaOH}$ concentration and later grow more intense. At relative $\mathrm{Al}$ rich gel, polymerized $\mathrm{Na}$ aluminosilicates grows with increasing of the number of bridge bonds (growing more intense) and decreasing of the number of terminal bonds.

Nevertheless, increasing $\mathrm{NaOH}$ concentration leads to the formation of rich Silica gel The band at $1032 \mathrm{~cm}^{-1}$ observed in MOSA treated with $4 \mathrm{M}$ solution moved back to high frequencies and grows more intense. The $\mathrm{Si}-\mathrm{O}^{-}$terminal bonds $\left(920-875 \mathrm{~cm}^{-1}\right)$ shows an increasing behavior in their intensities. In connection with that, it may be considered that the excess of $\mathrm{NaOH}$ concentration decrease polymerization process of reaction products [22]. The new bands appeared in the range of $500-800 \mathrm{~cm}^{-1}$ in the spectra of activated MOSA with $\mathrm{Al}$ rich gel precursor at 667 and $765 \mathrm{~cm}^{-1}$ are attributed to the 4-memebered singlering vibration of analcime, another bands are observed at 645 and $610 \mathrm{~cm}^{-1}$ which are due also to the same vibration referring to the literature $[42,44,45]$.The bands defined at 800 , 779 and $694 \mathrm{~cm}^{-1}$ are attributed to symmetric $\mathrm{Si}-\mathrm{O}$ stretching vibrations in quartz . The band at $460 \mathrm{~cm}^{-1}$ is attributed to the internal linkage of the $\mathrm{TO}_{4}(\mathrm{~T}=\mathrm{SI}, \mathrm{Al})$ tetrahedra related to zeolites materials.

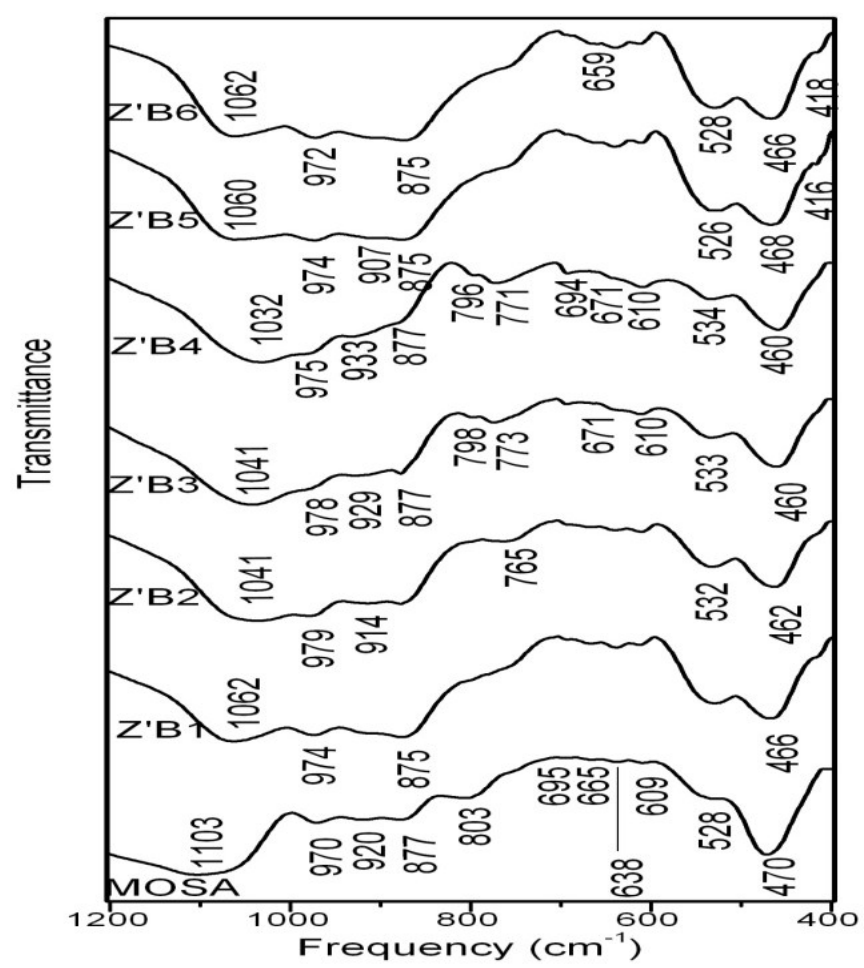

Figure 6. FTIR of the activated MOSA.

\section{SEM-EDX testing}

\section{Oil shale ash (OSA)}

The Major fired oil shale particles tends to be aggregated into a great deal of larger particles, which have a varied composition, with calcium and silicon as the dominant cations, and minor amounts of aluminum, magnesium, sulphur and iron. Scannining electron microscope of Fig. 7 shows the surface morphology of various observed structures. The most abundant of these structures has an elongated form [46]. On the other hand, quartz is present and can be seen clearly with Carbon deposed on its surface (fig. 8). 
Scanning electron microscope of the OSA sample shows well crystallized acicular-type crystals (structure 1). This typical of the wollastonite type crystal formed at heat treatment temperature of $900^{\circ}$ crystals which is the dominant phase [47]. Gehlenite occur as tetragonal-type structure (structure 2). On other hand, a brighten whisker (nanowires) type which was detected in different regions of the OSA sample is attributed to augite a glassceramic material (structure3). ].Finally a clear pseudo-cubic structure is detected on the middle which can be attributed to Anhydrite mineral (structure 4).

The EDX patterns in fig.7 indicate that the most phases in the sample contain $\mathrm{C}, \mathrm{O}, \mathrm{Mg}, \mathrm{Al}$, $\mathrm{Si}$ and $\mathrm{Ca}$. However it's clearly seen that nature of peak intensities corresponding to each element can help us to identify most structures, the compounds containing $\mathrm{Si}, \mathrm{O}, \mathrm{Al}$ and $\mathrm{Ca}$ with strong peak intensity may be identified as augite and gehlenite (structure 2 and 3).S was the predominant element in the structure 4 , which confirmed the identification of this phase as anhydrite.
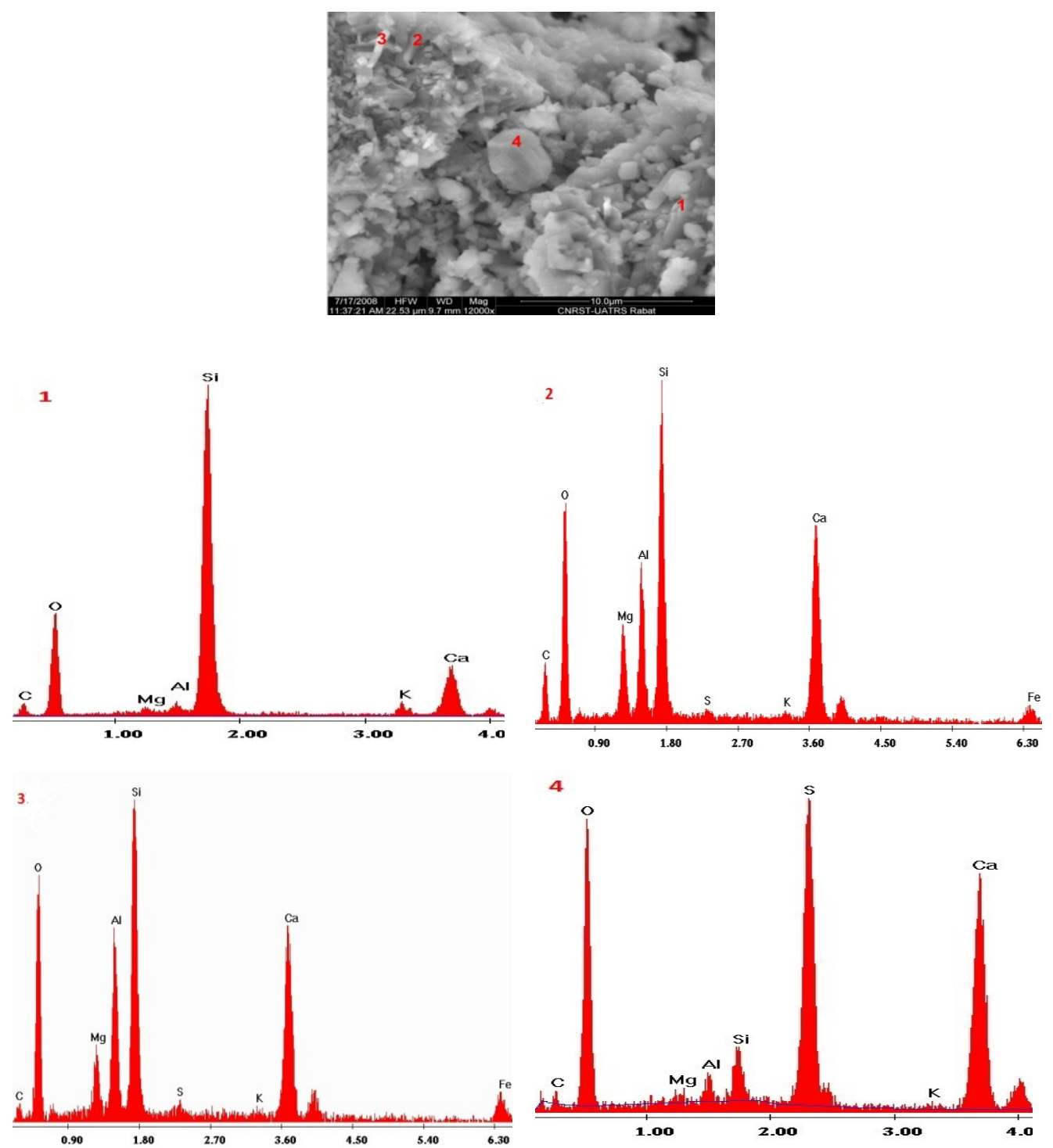
Figure 7. SEM and EDX images of OSA sample.

1: Wollastonite, 2: Gehlenite, 3: Augite and 4: Anhydrite.
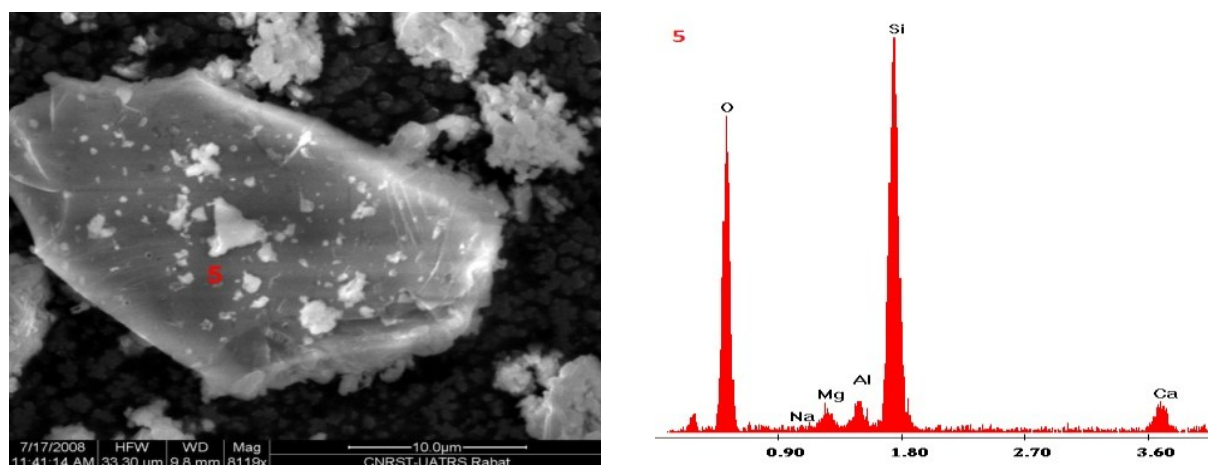

Figure 8. SEM image and EDX analysis of Quartz detected in OSA.

Modified oil shale ash (MOSA)

After acid treatment, only two phases were detected augite and quartz; as can be seen in Fig.9 the morphology of these phases is different from the first sample, we can observe more brighten aggregates related to amorphous phases. The EDX analysis of the modified oil shale ash shows a closer chemical composition but not the same peaks intensities.
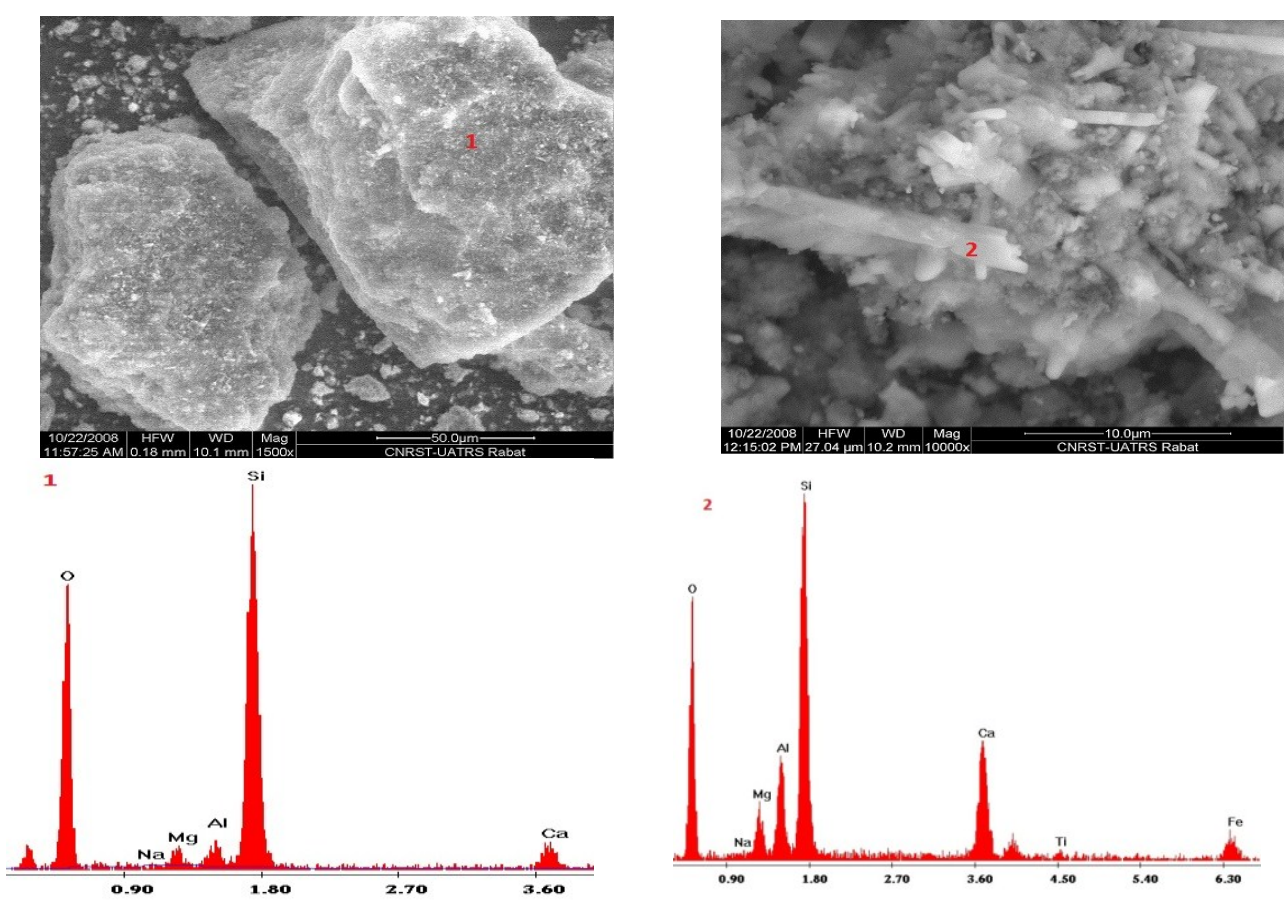

Figure 9. SEM and EDX of MOSA sample.

Alkali activated Oil shale ash (OSA) 
SEM observation of the samples produced under alkali activation of OSA revealed two different morphologies. In the reaction products ZB2 and ZB4 prepared respectively with 1 and $4 \mathrm{M} \mathrm{NaOH}$ concentration, a larger lath like structures were observed (Figs. 10-11(1)), similar to those of the Al-substituted tobermorite [48]. Figures 10-11 (2) show the EDS spectrum of the lathlike structures. $\mathrm{O}, \mathrm{Ca}$ and $\mathrm{Si}$ were detected as the predominant elements; it can be seen also the presence of the peaks related to $\mathrm{Al}, \mathrm{Mg}$ and $\mathrm{Na}$ this confirms the incorporation of these elements in the lathlike structures of tobermorite.
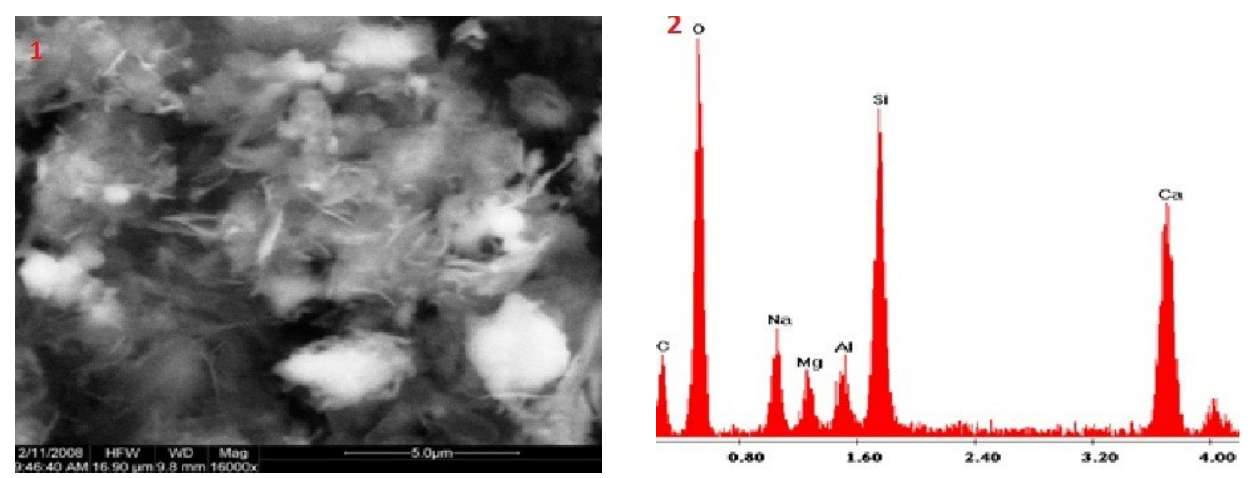

Figure 10. SEM (1) and EDX (2) of reaction product ZB2 (synthesized with $1 \mathrm{M} \mathrm{NaOH}$ ).
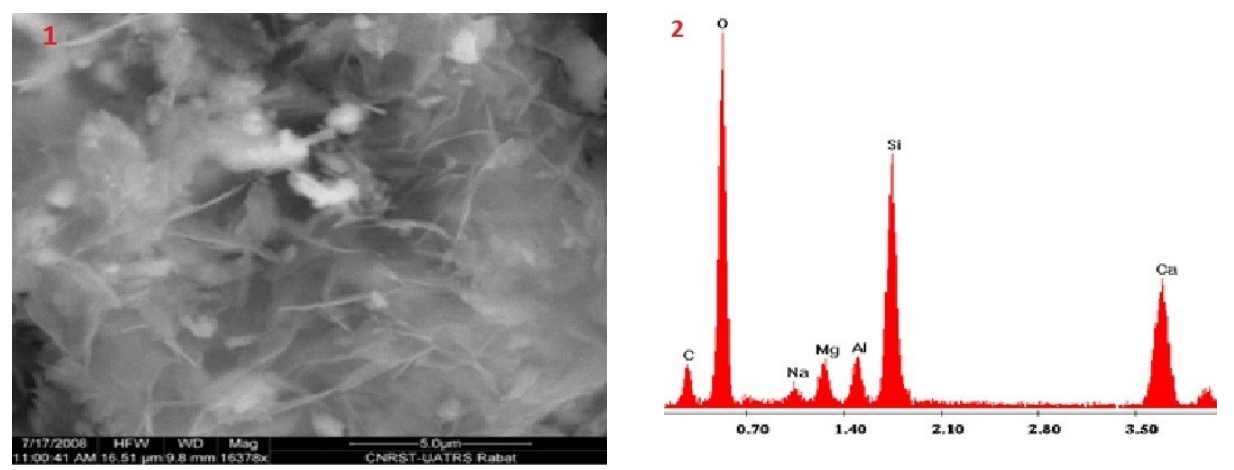

Figure 11. SEM (1) and EDX (2) of reaction product ZB4 (synthesized with 4M NaOH).

The second morphology observed in reaction products ZB6 consist of highly-crystalline cancrinite (Fig 12.1). The EDX analysis showed the presence of Carbonates and sulphates anions probably incorporated in cancrinite cage. Many previous works showed the role of those anions of the formation of high crystalline form of cancrinite [49].
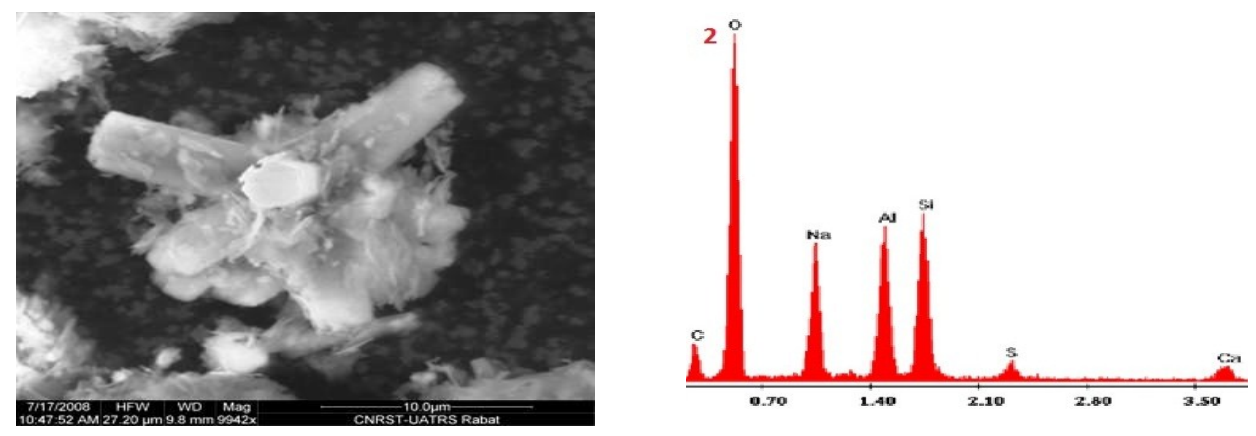
Figure 12. SEM (1) and EDX analysis (2) of the reaction product ZB6 (synthesized with 8 $\mathrm{M} \mathrm{NaOH})$.

\section{Alkali activated Modified oil shale ash (MOSA)}

SEM of Z'B4 sample a reaction products resulting from alkali activation of MOSA is shown in Fig13.1.A very small particles of analcime were detected in pseudo cubic form [50].

Nevertheless the Peaks position in XRD spectra matched closely with XRD PDF\#89-6324 which the crystal system is trigonal. The EDX analysis reveals the presence of the Calcium probably in lime form (Fig. 13 .2).
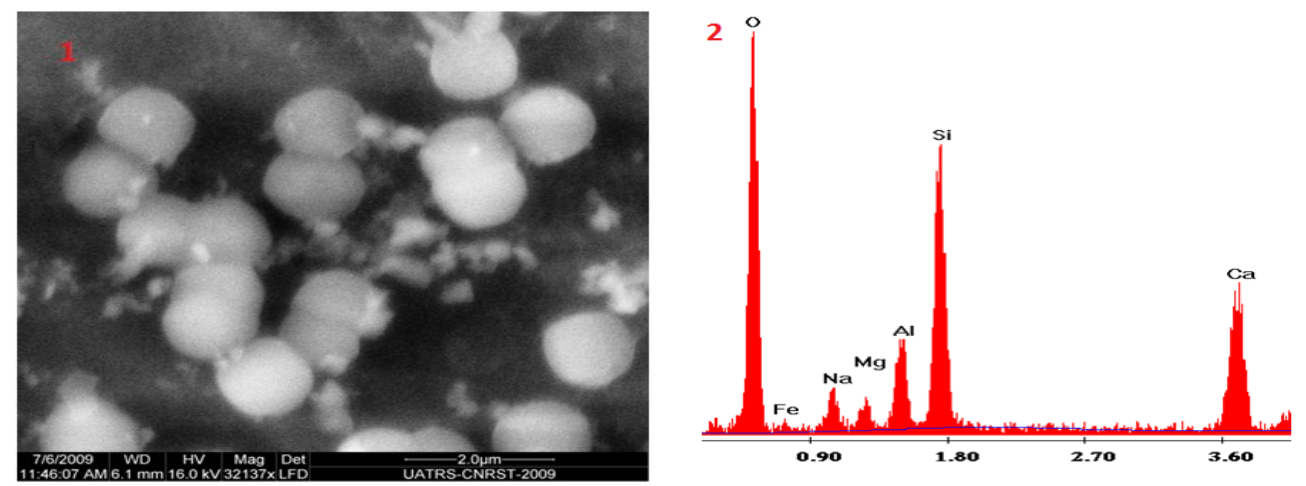

Figure 13. SEM (1) and EDX analysis (2) of the reaction product Z'B4 (synthesized with 4 $\mathrm{M} \mathrm{NaOH})$.

SEM of the Z'B6 sample MOSA is much more difficult to describe as the Fig 14 shows. It was almost impossible to detect the zeolitic material confirmed by $\mathrm{x}$ ray diffraction. This can be due probably to the presence of high percentage of amorphous phases in reaction products $(>52 \%)[22]$.

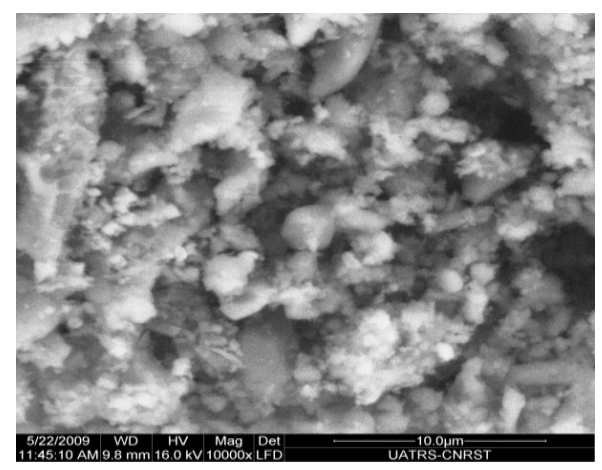

Figure 14. SEM of the reaction product Z'B6 (synthesized with $8 \mathrm{M} \mathrm{NaOH}$ ).

\section{Conclusion}

The results presented here prove that the Oil shale ash and (OSA) contain significant proportions of wollastonite, gehlenite and augite. The new phases were formed as a consequence of Ceramics processing applied to Timahdet oil shale. Therefore, under acid treatment, only augite remains unchanged while gehlenite and wollastonite were completely dissolved. 
Alkali activation treatment with $\mathrm{NaOH}$ solution of two different starting materials: oil shale ash (OSA) and modified oil shale ash (MOSA) has been studied. The experimental results provide many conclusions concerning the conditions of alkali activation of OSA and MOSA.

- DRX and FTIR analysis of alkali activated OSA suggest that gehlenite is the least resistant material compared with wollastonite and augite.

- Under alkaline conditions, gehlenite dissolved to release $\mathrm{Ca}, \mathrm{Al}$ and $\mathrm{Si}$.

- The presence of lathlike structure observed in reaction products synthesized with OSA and $1 \mathrm{M} \mathrm{NaOH}$ solution is attributed to tobermorite. In addition the resulting tobermorite accommodates $\mathrm{Al}$ as shown by the EDS analysis.

- Dissolution of quartz increased with increasing $\mathrm{NaOH}$ concentration. Whereas $\mathrm{Si}$ content affect the crystallization of the reaction products.

- Cancrinite is developed as consequence of alkali activation of OSA ( $9 \%$ for high $\mathrm{NaOH}$ concentration).

- Modified oil shale ash displays high reactivity in alkaline conditions. Pure phase of analcime was found in the reaction products. The optimum conditions were realized for $4 \mathrm{M} \mathrm{NaOH}$. However, when the $\mathrm{NaOH}$ concentration was set superior to $4 \mathrm{M}$, a few amount of cancrinite (12\%) was found suggesting that the excess of $\mathrm{NaOH}$ seems to cause deploymerization of aluminosilicates disfavoring the zeolites formation.

- Zeolites formation is critically affected by the $\mathrm{NaOH}$ concentration and $\mathrm{Si} / \mathrm{Al}$ ratio.

\section{Acknowledgements}

Analytical instrument facilities were provided by the UATRS-CNRST (Unité d'Appui à la Recherche Scientifique-Centre National de la Recherche Scientifique et Technique), Rabat, Morocco. We are indebted to Mr. Zouihri Hafid for help with collecting X-ray powder diffraction, Mr. Dakhsi Khalid for assistance with SEM/ EDS collection and observations and Mr. Annour Khalid for FTIR analysis.

\section{References}

1. Office nationale des hydrocarbures et des mines (ONYHM). http://www.onhym.com/.

2. Jaber J O and Probert S D, App Energy, 1999, 62, 169-209.

3. Toomik A and Liblik V, Land Urb Plan., 1998, 41 285-292.

4. HE Y G, oil shale. 2004, 21(3), 259-264.

5. Smadi M M and Hadda R H, Cem Concr Comp., 2003, 25, 43-50.

6. Nabih K, Caractérisation et traitements thermiques des schistes bitumeux des sous couches R de Tarfaya sous différentes atmosphères (N2, He, air et vapeur d'eau), Utilisation du Ciment dans la production du ciment. D Etat thesis 1997 at university of Mohamed V (Rabat-Morocco).

7. Yoffe O, Nathan Y, Wolfarth A, Cohen S and Shoval S, Fuel, 2002, 81, 1101-17.

8. Jingde Luan, Aimin Li, Tong Su, Xiaobo Cui and Haza J, Mat.,2010, 143, 427-432.

9. Hajjaji M and Khalfaoui A, Cons Build Mater., 2009, 23, 959-966.

10. Fernandes Machado N R C and Malachini Miotto D M, Fuel, 2005, 84, 2289-2294.

11. Shawabkeh R, Al-Harahsheh A, Hami M and Khlaifat A, Fuel, 2004, 83,981-985.

12. Henmi T, Soil Sci Plant Nutr., 1987, 33, 519-523.

13. Beylrs P, Amer Miner., 1976, 61, 334-336.

14. Grzeta B and Popovic S, J Appl Cryst., 1985, 18, 80-84.

15. Ohashi Y and Finger L W, Amer Miner., 1978, 63, 274-288.

16. PETERS T and IBERGA R, Amer Ceram Soc Bull., 1978, 57, 503-509. 
17. Korczak P and Raaz F, OEAW Math Naturwissenschaftliche Klasse., 1967, 104, 383387.

18. Bowen N L, The evolution of igneous rocks; Princeton University press: NJ,1928, 321-322.

19. M. Okui , Haruo S and Fumiyuki M, Phys Chem Miner.,1998, 25, 318-322.

20. Kern A and Eysel W, Mineralogisch-Petrograph Inst Univ Heidelberg., Germany, ICDD Grant-in-Aid, 1993.

21. Swanson H E, Fuyar R K and Ugrinnic G M, Nat Bur Stand U.5. Circ., 1955, 539, 467.

22. Khale D and Chaudhary R, J Mater Sci., 2007, 42, 729-746.

23. The International Centre for Diffraction Data File No. 19-1364.

24. Shaw S, Clark S M and Henderson C M B, Chem Geo., 2000, 167, 129-140.

25. HACKBARTH K, GESING T M, FECHTELKORD M, STIEF F and BUHL J C, Micropor. mesopor. mater., 1999, 30, 347-358.

26. YOKOMORI Y and IDAKA I, Micropor Mesopor Mater.,1998, 21, 365-370.

27. Smolin Y I, Shepelev Y F, Butikova I K and Kobyakov I B, Soviet Phys Crys., 1981,26, 33-35.

28. Rutstein M S and White W B, Am Mineral., 1971, 56,877-887.

29. Sterns R G J. The common chain ribbon and ring silicates, in: V.C. Farmer (ED). Infrared spectra of Minerals. Mineralogical society London, UK, 1974.

30. Kimata M, N Jb Miner Abh., 1980, 139, 43-58.

31. Dowty E, Phys Chem Mineral, 1987, 14,122-138.

32. Omori K, Am Mineral., 197, 56, 1607-1616.

33. Goel A, Tulyaganov D U, Kansal I, Shaaban E R and Ferreira J M F, Inter J Mater Eng Innov., 2009, 1, 40-60.

34. Makreski P, Jovanovski G, Gajović A, Biljan T, Angelovsk D and Jaćimović R, J Mol Struc., 2006, 788, 102-114.

35. Nicodm. Inorganic library of FTIR spectra-Minerals, 1998.

36. Hamilton V E, J G R., 2000, 105, 9701-9716.

37. Griffiths P R, Clark R J H and Hester Eds R E, Recent Commercial Instrumental Developments in Fourier Transform Infrared Spectrometry; in Advances in Infrared and Raman Spectroscopy; Heyden Publishing Co: London,1983, vol.10, Chapter 5, 277-306.

38. Lin S-L and Hwang C-S, J Non-cryst solide., 1996, 202, 61-67.

39. Fernandez-Jimenez A, Palomo A, Micropor Mesopor Mater., 2005, 86, 207-214.

40. Barnes M C , ddai-Mensah A J and Gerson A R, Micropor Mesopor Mater.,1999, 31,287-302.

41. Zhao H, Deng Y, Harsh J B, Flury M and Boyle J S, Clays Miner., 2004, 52, 1-13.

42. Mozgawa W, Sitarz M and Rokita M, J Mol Struc., 1999, 511, 251-257.

43. Criado M, Fernandez-Jimenez A and Palomo Q, Micropor Misopor Mater.,2007, 106, 180-191.

44. Rios C A, Williams C D and Castellanos O M, Bistua, 2004, 4, 60-71.

45. Barbrieri E, corraadi A and Lanceloti I, Eur J Ceram Soc., 2000, 20, 1637-1643.

46. Cultrone G, Rodriguez-Navarro C, Sebastian E, cazalla O and De la torre M J, Eur J Mater., 2005, 13, 621-634.

47. Bernardo E, Bonomo E and Dattoli A, Ceram Inter., 2010, 36, 1675-1680.

48. Mostafaa N Y, Kisharb E A, Abo-El-Eneinc S A, J Allo Comp., 2009,473, 538-542.

49. Deng Y, Flury M, Harsh J B, Felmy A R and Qafoku O, App Geochem., 2006, 21, 2049-2063.

50. Sandoval M V, Henao, J A, Rios C A and Williams, D.C, Fuel, 2009, 88, 272-281. 


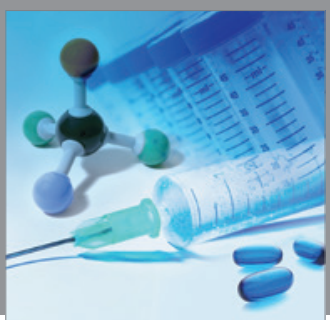

International Journal of

Medicinal Chemistry

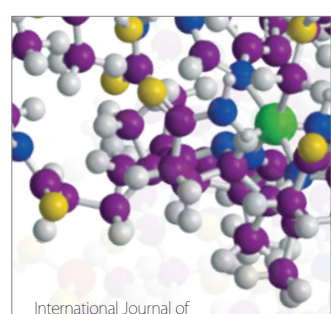

Carbohydrate Chemistry

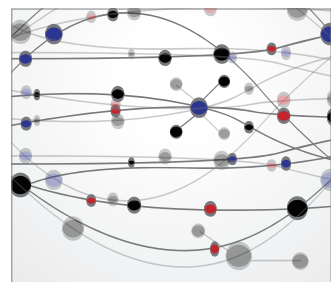

The Scientific World Journal
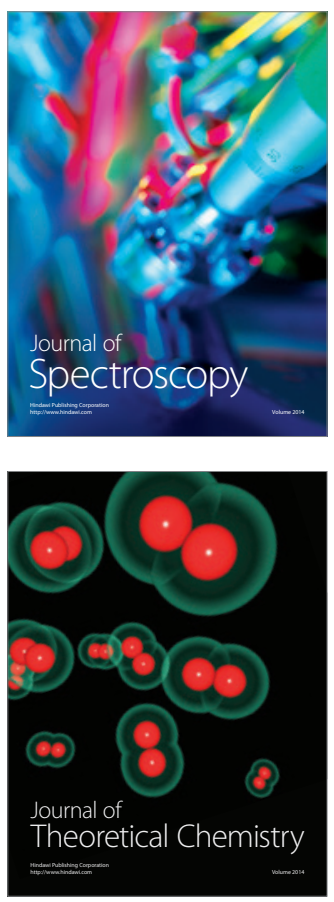
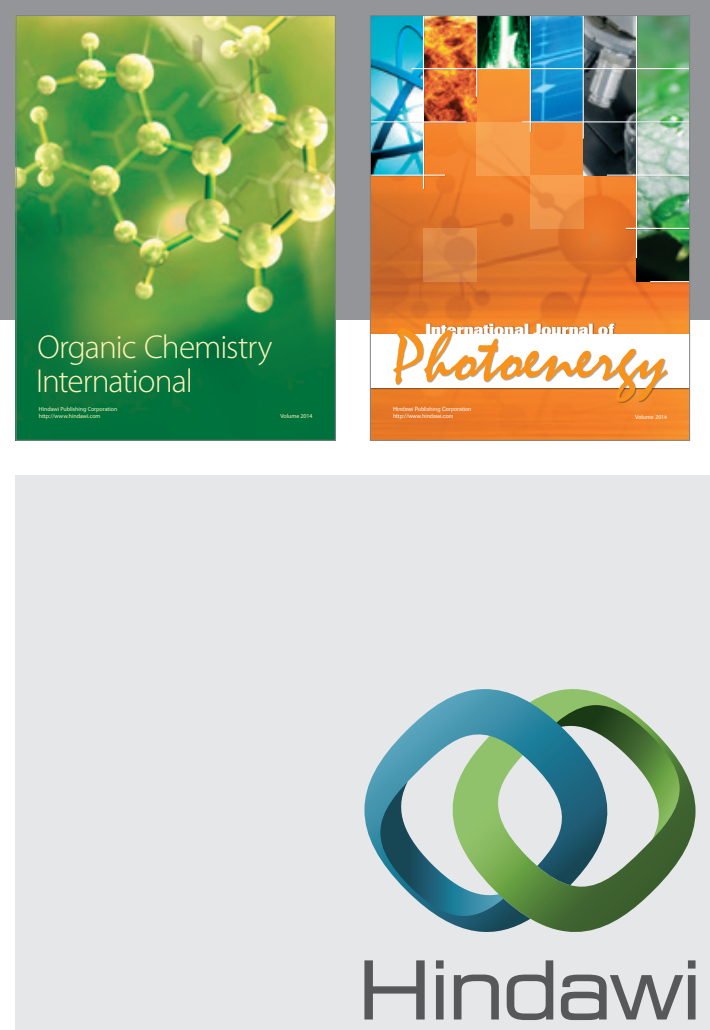

Submit your manuscripts at

http://www.hindawi.com
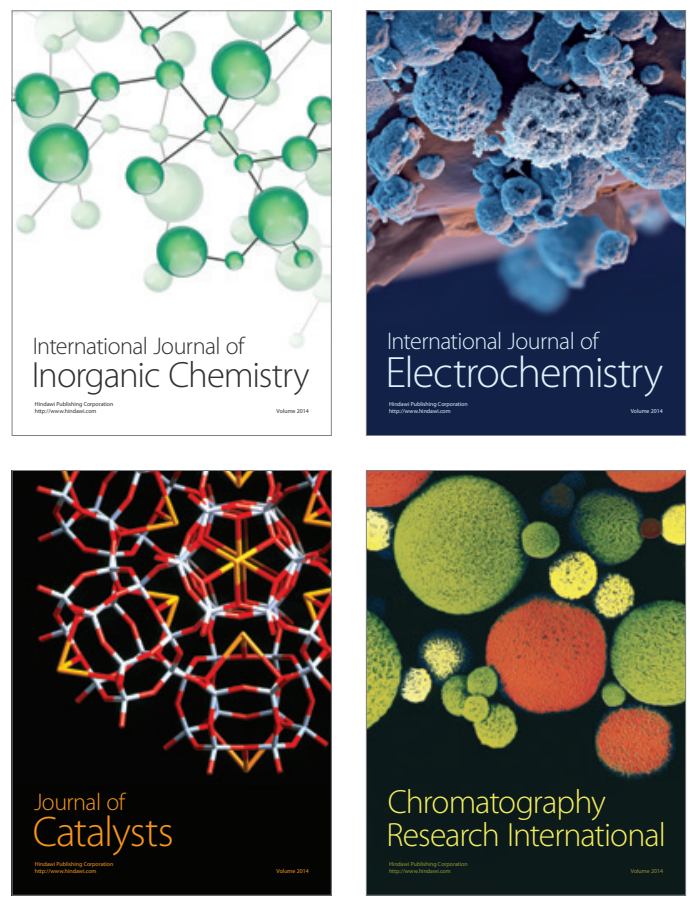
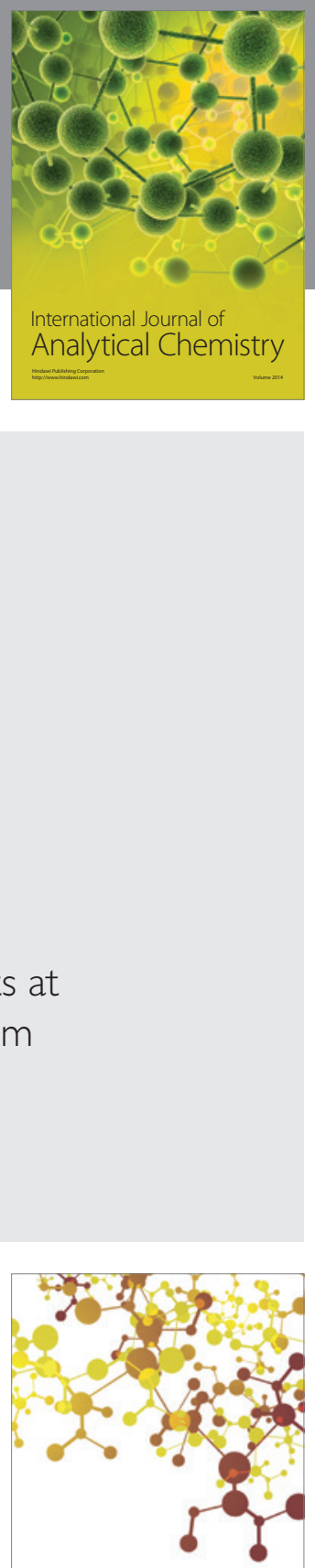

Journal of

Applied Chemistry
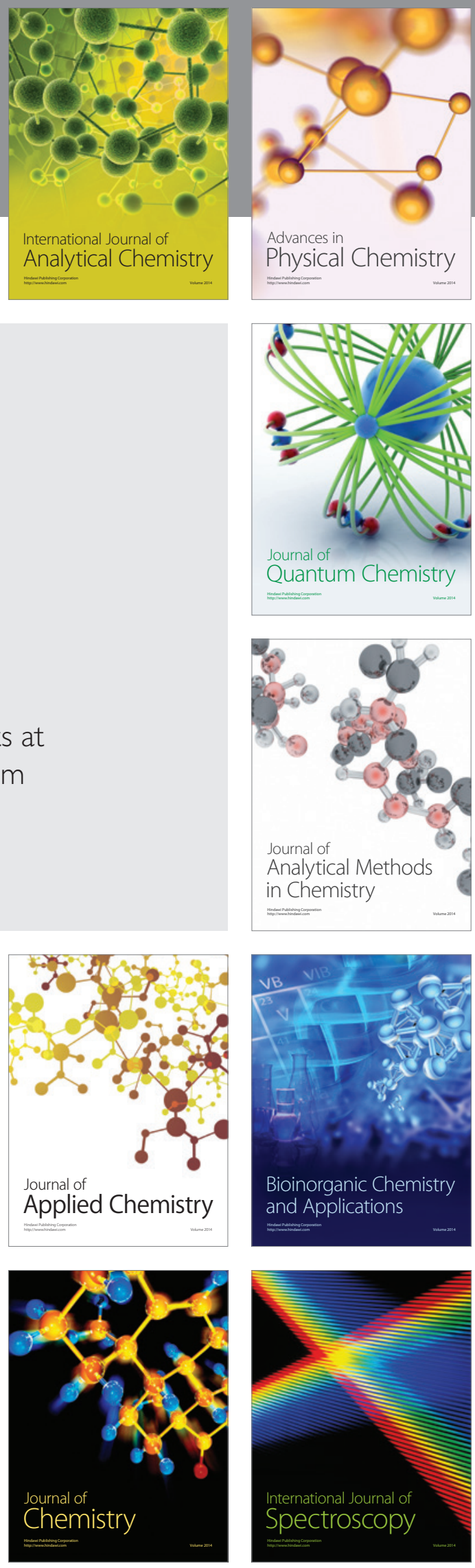